\title{
賠償責任保険において保険金から優先的 な被害の回復を行う方法について
}

——被害者の直接請求権, 特別先取特権の問題を中心に

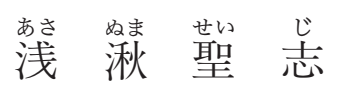

\section{ロアブストラクト}

法制審議会保険法部会において，規律の現代化として幾つかの新たな試み が審議されている。その中で, 賠償責任保険契約に固有の事項として検討が 進为られている「保険金から優先的な被害の回復を行う方法」について，一 定の条件が付された「直接請求権」や「特別先取特権」を制度として設ける ことが提案されている。こうした制度の創設には，実務的には多くの八ード ルがあるので，その問題点を明らかにしながら，どのような条件のもとであ れば実効性のある制度が立ち上げられるのか，実務家の立場から考察した。

\section{ロキーワード}

賠償責任保険，直接請求権，特別先取特権

\section{1．賠償責任保険で被害者を救済するための方策}

最初に，賠償責任保険で被害者を救済するための方策に関する分類を行い， それぞれの基本的な考え方や前提，および問題点などをまとめてみた。

\section{（1）強制保険について被害者から保険者への直接請求権を認める方法 \\ (1) 基本的な考え方}

*平成19年 9 月 26 日の関東部会での報告による。

/ 平成19年10月15日原稿受領。 
賠償責任保険において保険金から優先的な被害の回復を行う方法について

法律によって加入が義務付けられている賠償責任保険は，目的が被害者 の救済であることが明確であり，直接請求権を定めるというものである。

(2)検討に当たっての前提・問題点

強制保険の場合には，付保強制に実効性を持たせており，強制保険の内 容の開示についても懸念されるべき問題は少ない。また，加害者（被保険 者）の責任や賠償の基準なども明らかにされていることが多いため，強制 保険に限って被害者から保険者への直接請求権を認めることについて，実 務面での支障は少ないと考えられる。

\section{（2）被害者が加害者からの被害回復を受けられない場合に，第三者たる保険 者が被害者に保険金を直接支払う方法}

(1) 基本的な考之方

保険事故が発生した後に，加害者たる被保険者が破産手続きの開始の決 定を受けた場合には，基本的には被保険者による賠償金の支払いがなされ ず，被保険者が保険者に対して，被害者への保険金の支払い指図をするこ とも出来ないことから，被害者の側は十分な被害の回復が受けられないこ ととなる11。こうした，法律によって手当てされなければ解決できないケ 一スに限って，被害者救済のために任意に加入する保険であっても，被害 者からの直接請求を認める ${ }^{2)}$ ，あるいは被害者の損害賠償請求権に関し，

1）山下友信『保険法』(有斐閣) 初版，2005年，P442。

「被保険者が責任保険でてん補される責任を負い保険金請求権が発生すると， 被害者以外の一般債権者の一般責任財産からの弁済率が上昇するという珍妙な 結果になる」と評されている。

2）イギリスでは1930年第三当事者法に直接請求権の記載がある。要約すると以 下の通り。

(1)被害者に対する被保険者の権利移転

被保険者が破産したり，法人の場合清算命令が発せられたなどの場合でそ の前後で被保険者の賠償責任が発生するときには，その責任に関する保険契 約に基づく保険者に対する被保険者の権利は被害者に移転する。

(2)破産者などの被害者に対する情報開示義務 
保険金についての特別の先取特権を導入するというものである。

(2) 検討にあたっての前提・問題点

以下(2)から(4)までに共通であるが，強制保険に限らず任意に加入する賠 償責任保険も視野に入れる場合，実務を考えると解決されなければならな い問題や前提が多い。代表的なものを挙げると以下の通りである。

・保険者は紛争の直接の当事者ではなく，また事実関係の調査権限を持た ないこともあり，自らの力だけでは責任の有無，責任の割合を判断する ことが出来ないので，こうしたことについて実効性を確保する仕組みが 保証されていなければならない。

・加害者側に賠償責任保険が付されているかどうかを開示させる仕組みが なければ，被害者は保険金からの給付を求めることが保証されないので， 契約の開示の仕組みが整っていなければならない。

\section{（3）一定の賠償責任保険について保険者が示談交渉を行う方法}

(1) 基本的な考え方

個人契約を中心に，被保険者に対して，保険者が示談交涉サービス付の 賠償責任保険を提供し，その要素の一つとして被害者の直接請求権を定め るというものである。保険者が示談を代行することにより，被保険者にと っては煩頊な法律事務から解放されるというメリットが生じ，一方被害者 側にとっては適切な補償が受けられ，スムーズな賠償事故解決が図られる というメリットが生じる。

(2) 検討に当たっての前提・問題点

前記(2)(2)の問題は，強制保険以外の保険に共通しているが，一般的に企 業契約者に比べると個人契約者の場合には，自らが付保している保険を開 示することの抵抗感が少ないこと，生産物賠償責任保険で問題となるよう

破産者や破産管財人などは被害者側の請求に基づき，本法による権利移転 があるか，その権利を行使するかどうかなどについて判断するために必要な 情報を提供する義務を負う。 
賠償責任保険において保険金から優先的な被害の回復を行う方法について

な企業秘密の問題がないこと，また法律問題から解放されたいというニー ズが強いと考えられること，などから，解決されるべき問題は事実確認な ど一定のものに絞られてくる。

一方で，日常生活に起因する事故の補償に，保険者による示談交渉サ一 ビス付の保険を導入する場合には，個人間の単なるトラブルに第三者であ る保険者が介入する場面が増えていくことが容易に想定されるため,

・弁護士法第72条との関係での非弁活動の問題

・「保険に加入しているから大丈夫」といった意識から注意が散漫になり， 広い意味でのモラルバザードが顕在化する問題

など様々な問題が生じることが懸念される。

\section{（4）人身に関する賠償責任保険に限って被害者から保険者への直接請求権を 認める方法}

(1) 基本的な考之方

被害者が救済されるべきケースを絞って，被害者保護の要請が強い人身 損害に限って，被害者に対する被害回復の実効性を高めようとする考え方 で，個人の生命・身体の障害に対しては，政策的な配慮から直接請求権を 認めるというものである。

(2) 検討に当たっての前提・問題点

D\&O 保険のようなケースに比べれば，被害者保護の要請が強いことに ついてはコンセンサスが得られやすいと思われるが, 理屈立ては必要であ る。また，対象が個人の生命・身体の障害に限られるため，対象となる賠 償事故の絶対数が少なくなることは明らかであるが，(2)(2)に記載した問題 が解決されなければ実効性のある被害者救済はなされないことになる。

なお，以上の(1)から(4)までの内容については，その組み合わせなどにより 適用範囲を広げる（例えば，強制保険に加えて，被保険者が破産した場合に 限って任意の賠償責任保険に被害者の直接請求権を導入する)，或いは狭め 
る（例えば，被保険者が破産した場合で，かつ人的な損害に限って被害者の 直接請求権を導入する）といったことも検討の対象となると考えられる ${ }^{3)}$ 。

\section{2 。賠償責任保険の位置づけについての考え}

\section{（1） 賠償責任保険は誰のための，何のための保険か}

賠償責任保険は，被保険者が他人に対して一定の財産的給付をなすべき法 律上の損害賠償責任を負担することによって被る財産上の損害をてん補する 保険である ${ }^{4)}$ 。損害賠償責任の発生は，加害者の過失に起因するので，賠償 責任保険は原則として被保険者の過失を担保することを目的とすることとな る。したがって，第一義的には賠償責任保険は被保険者の賠償損害をてん補 する機能を有するということになる。保険者が保険金を支払うべき相手方は 被保険者であり，保険契約の当事者でない被害者に対して，保険者が保険金 の支払い義務を負うことはないはずである。

実際の契約においても，保険契約者側がリスクマネジメントを行う中で， 保険契約者側の判断により，1名当たりの限度額や 1 事故・期間中の総てん 補限度額, 加えて被保険者の自己負担額の設定が行われることになる。これ らの条件は, 被害者の不知の領域で決定されることからも，保険契約者が被 保険者のリスクを回避する手段として締結する保険契約であるということは 明確である。

一方，加害者である被保険者の賠償資力を確保することで，その反射的な 効果として被害者の保護が図られることになる。したがって，保険者の支払 う保険金については，最終的には被害者に対する被保険者の債務の履行とい う目的に利用される必要性があることについても，当然着目する必要がある。

3）このほかに債権者代位による保全も検討されるべきという考え方があるが, 無資力要件の問題や債権法改正の論議では債権者代位の制度そのものの廃止論 もあることからここでは敢えて取り上げなかった。

4) 東京海上火災保険『損害保険実務講座 7 新種保険（上）』(有斐閣) 初版, 1989年，P262。 
賠償責任保険において保険金から優先的な被害の回復を行う方法について

\section{（2）被害者の直接請求権に関する一般論}

賠償責任保険における第三者の直接請求権は, 賠償責任保険の性質上当然

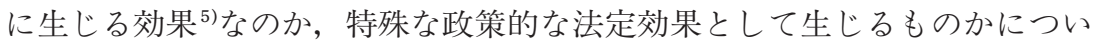
ては議論があるところであるが，通説的な考え方は後者であるということに 落ち着いていると思われる ${ }^{6)}$ 。およそ全ての賠償責任保険に関して言えば, 保険契約の当事者ではない被害者には直接請求権は認められず，同権利を付 与するためには，法律上の規定または保険契約上の約定が必要ということに なる。

法令，約款に直接請求権の規定がない場合において，保険者への直接請求 が争われた裁判例については，下級審で否定した例（東京地判 S 53.11.30判 例時報924号，P115）があるが，最高裁における判例はない。なお，破産し た被保険者の生産物賠償責任保険の保険金請求にかかる債権者代位を否定寸 る判断理由の中で，「生産物賠償保険とは・・不測の損害賠償義務を負担す ることによる企業の経営上のリスクを回避する目的で締結されるものである から，被害者の救済はその反射的な利益に止まる」（東京地判H14.3.13判例 時報1792号，P78，この判例については詳しくは後記 3 (1)で述べる）と判示 しており，その後の上告審でもその結論が維持されていることから，被害者 のためにする保険契約との性格を強調することにより直接請求権を根拠付け るという考え方は，判例上は否認されていると解される。

\section{（3）自賠責保険と自動車保険に見られる直接請求権の差異}

自賠責保険の直接請求権と自動車保険の直接請求権とでは，自賠責保険の 場合，民法の特別法として規定された自動車損害賠償保障法（以下「自賠 法」という。）に基づく権利であるのに対し，自動車保険の場合，示談交渉

5）被害者直接請求権の根拠を「加害者の責任免脱」という賠償責任保険制度の 目的に求める見解や，「被害者保護機能」が賠償責任保険の主要な目的であり, 賠償責任保険を被害者のためにする保険契約とする見解が代表的である。

6) 宮島司『自動車保険の法律問題 金融商事判例別冊No.3』(経済法令研究 会)，1991年，P38。 
サービス付きの自動車保険商品を販売するにあたって導入された約款に基づ く権利であるという点で, 同じ直接請求権と言っても内容も実際の運用も大 きく異なっている。

自賠法の被害者直接請求権は, 自賠法に固有の特殊な権利である。自賠法 の直接請求権は, 被保険者の保険金請求権から切り離されて独自のものとし て構成されているので，被保険者に対して主張可能な一切の抗弁を，保険者 は被害者に主張出来ない内容になっている。これに対して，自動車保険では， 約款で被保険者の保険者に対する直接請求権が認められている。これは，保 険契約者と保険者との間で民法第537条の「第三者のための契約」という法 形式で規定されている。したがって，被害者たる第三者は保険契約者と保険 者間の契約内容によって権利の制限を受けることになる。具体的には，被保

\begin{tabular}{|c|c|c|}
\hline 項目 & 自賠責保険 & 対人賠償責任保険 \\
\hline $\begin{array}{l}\text { 直接請求権の根 } \\
\text { 拠 }\end{array}$ & $\begin{array}{l}\text { 自賠法によって特別に認めら } \\
\text { れた権利（自賠法第16条） }\end{array}$ & 約款に基づく権利 \\
\hline $\begin{array}{l}\text { 直接請求権の発 } \\
\text { 生時期 }\end{array}$ & $\begin{array}{l}\text { 保有者の損害賠償責任が生じ } \\
\text { た時に発生（自賠法第16条） }\end{array}$ & $\begin{array}{l}\text { 被保険者の負担する法律上の } \\
\text { 損害賠償責任が発生した場合, } \\
\text { 被害者が保険者に対して直接 } \\
\text { 請求をしたときに発生 }\end{array}$ \\
\hline $\begin{array}{l}\text { 被保険者に対し } \\
\text { て適用される免 } \\
\text { 責規定の適用 }\end{array}$ & $\begin{array}{l}\text { 被害者に対しては適用されな } \\
\text { い(自賠法第16条)。 }\end{array}$ & $\begin{array}{l}\text { 被害者に対してそのまま適用 } \\
\text { される。 }\end{array}$ \\
\hline 支払条件 & なし & あり \\
\hline $\begin{array}{l}\text { 直接請求権の行 } \\
\text { 使期限または時 } \\
\text { 効 }\end{array}$ & $\begin{array}{l}\text { 直接請求権は被害者が加害者 } \\
\text { および損害を知った時から } 2 \\
\text { 年を経過したときは時効によ } \\
\text { て消滅する（自賠法第19 } \\
\text { 条)。 }\end{array}$ & $\begin{array}{l}\text { 直接請求権は被害者と被保険 } \\
\text { 者の間で損害賠償責任の額が } \\
\text { 確定した時から } 2 \text { 年を経過し } \\
\text { たとき, まな被害者の被保 } \\
\text { 険者に対する損害賠償請求権 } \\
\text { が時効によって消滅したと年よ出な。 } \\
\text { は行使で出来ない。 }\end{array}$ \\
\hline $\begin{array}{l}\text { 直接請求権の差 } \\
\text { 押え }\end{array}$ & $\begin{array}{l}\text { 被害者の債権者は直接請求権 } \\
\text { を差し押さえることは出来な } \\
\text { い(自賠法第18条)。 }\end{array}$ & $\begin{array}{l}\text { 被害者の債権者は直接請求権 } \\
\text { を差し押さえることが出来る。 }\end{array}$ \\
\hline
\end{tabular}


賠償責任保険において保険金から優先的な被害の回復を行う方法について

険者に対する免責規定がそのまま被害者に対しても適用されるなど，保険者 は被保険者に対して主張できる抗弁を被害者に対しても主張できる ${ }^{7) 。}$

主な相違点を表にまとめると前頁の通り。

次に，自賠責保険と自動車保険における直接請求権が行使される具体的な 場面について記載する。自賠責保険の場合, 請求の多くは加害者請求（自賠 法第15条の請求) が占める ${ }^{8)}$ が，被害者の直接請求権が行使される場合もあ る。主に以下のケースである。

ア 請求者側の過失割合が大きく，自賠責保険の範囲内で支払いが終了する 場合（過失の大きい交通事故被害者が請求するケース）

イ 被害者が死亡したり，後遺障害を負ったりした場合で，被害者（遺族も 含む）と保険者との示談交渉が長引くとき，加害者からの内払いを拒み， 自賠法で認められた金額を被害者が自賠責保険に請求する場合

これに対し，自動車保険では，実務上被害者直接請求に基づき保険金を支 払うことは殆どない。私見であるが，加害者側である被保険者が保険者に示 談交渉を依頼して保険者がその対応をすることが通例であることや，約款上 保険金の支払要件（被保険者またはその法定相続人の破産など）が定められ ており，当該要件に当てはまるケースが殆どないのがその原因であると考え られる。ただし，行使要件（事故によって被保険者の負担する法律上の損害 賠償責任が発生した場合など）が定められているために，被害者側から訴訟 を提起する場合には，この直接請求権に基づいて加害者とともに保険者も相 手方として訴訟を行うことができる。

7）約款では，被害者に支払う損害賠償額の限度は「被保険者に対しててん補責 任を負う限度」および「当会社が，この賠償責任条項および一般条項に従い被 保険者に対して支払うべき保険金の額」としており，このことは単に保険者の 支払限度額を規定しているだけではなく，約款上の免責事由や告知義務違反な どにより保険者が被保険者に対しててん補責任を負わない場合は，損害賠償額 も支払われないことを意味している (民法第539条)。

8）平成17年度の自賠責保険における被害者請求の比率は，死亡の場合で $26.5 \%$, 傷害の場合で $11.9 \%$ である。（損害保険料率算出機構からのヒアリング結果） 


\section{（4）自動車・自賠責保険と一般の賠償責任保険の差異}

一般の賠償責任保険には，施設所有者賠責などの企業向けの商品，ゴルフ ア一保険などの個人向けの商品, 医師賠責などの専門職業人向けの商品のほ かに自動車保険，海上保険など幅広い保険の分野で賠償リスクを補償する商 品がある。このように多岐にわたる賠償責任保険の分野において，被害者に 直接請求権を持たせる実務を問題なく運用するためには，紛争解決のノウ八 ウや定型的な処理が可能なことが前提になるが，次頁の整理の通り自動車保 険以外の例えば企業向けの保険や新たな賠償責任保険では，制度導入に伴う 問題が顕在化することは明らかである。

また，自賠責保険，自動車保険ともに 1 事故の賠償限度額は設けられてい ない。1事故の賠償限度額を無制限とすることの実効性を確保するため，自 賠責保険も自動車保険も「再保険プール」を用意している。これに対して, 新たなリスクが今後予想される賠償責任保険では，1事故の賠償限度額を設 けないとすることは，リスクの特性の関係から難しい。こうした，制度面の 整備もこの問題を考える上での重要な要素の一つである。

例えば，食品や薬品関係の生産物賠償事故の場合，被害者が長期間摂取す ることにより発生する蓄積損害や，人体に取り込まれた後，一定期間経過後 に被害が出てくる遅発損害が容易に想定される。被害総額が予測できないた め，保険者としても一定の限度額を設ける必要性があることや，発症時期に 差が出るため先に症状が出た被害者は救済されるが，後になって症状が出る 被害者は，保険契約上の限度額を超えている場合に当該保険では補償されな いなど，被害者間の公平な賠償を行うこと自体，現実的には難しいといった 問題が指摘される9 。

9）生産物賠償責任保険は，保険期間中に損害賠償請求を受けたことが「保険事 故」となるため，賠償責任保険の補償の対象となる事案は「保険期間中に損害 賠償請求があった事案」に限定されており，もともと無期限に保険で補償され ているわけではない。 
賠償責任保険において保険金から優先的な被害の回復を行う方法について

\begin{tabular}{|c|c|c|c|}
\hline & 自動車保険 & $\begin{array}{l}\text { 生産物賠償責任保 } \\
\text { 険を中心とした企 } \\
\text { 業向け賠償責任保 } \\
\text { 険 }\end{array}$ & $\begin{array}{l}\text { (保険者の観点から) 生 } \\
\text { 産物賠償責任保険を中心 } \\
\text { とした企業向け賠償責任 } \\
\text { 保険における問題点 }\end{array}$ \\
\hline $\begin{array}{l}\text { 事故の態様, } \\
\text { 被害の程度 }\end{array}$ & $\begin{array}{l}\text { 定型的, 類型化可 } \\
\text { 能 }\end{array}$ & 多種多様 & $\begin{array}{l}\text { 紛争解決ノウハウの蓄積 } \\
\text { および体制構築が難しく, } \\
\text { コストもかかる。 }\end{array}$ \\
\hline $\begin{array}{l}\text { 事故発生の } \\
\text { 頻度・件数 }\end{array}$ & 高頻度, 大量 & 多種多様 & 同上 \\
\hline $\begin{array}{l}\text { 事故原因, } \\
\text { 被保険者の } \\
\text { 責任の有無 }\end{array}$ & $\begin{array}{l}\text { 判明し易い } \\
\text { 警察の実況検分な } \\
\text { ど事実把握が容易 }\end{array}$ & $\begin{array}{l}\text { 判明しづらい } \\
\text { 原因の解明には一 } \\
\text { 定の専門的な調査 } \\
\text { が必要 }\end{array}$ & $\begin{array}{l}\text { 損害賠償額の判断だけで } \\
\text { は済まない。 }\end{array}$ \\
\hline $\begin{array}{l}\text { 責任の有無 } \\
\text { の認定, 損 } \\
\text { 害額の算定 }\end{array}$ & $\begin{array}{l}\text { 一定の基準に従っ } \\
\text { て判断可能 } \\
\text { 賠償基準が確立さ } \\
\text { れている }{ }^{10)} \text { 。 } \\
\text { 紛争解決手段が整 } \\
\text { っている }{ }^{11)} \text { 。 }\end{array}$ & $\begin{array}{l}\text { 個別性が高い。 } \\
\text { 賠償基準は確立さ } \\
\text { れていない。 } \\
\text { 紛争解決手段が整 } \\
\text { 備されているとは } \\
\text { 限らない。 }\end{array}$ & $\begin{array}{l}\text { 紛争解決にかかる労力が } \\
\text { 大きい。被保険者の企業 } \\
\text { 秘密（製品の製造工程や } \\
\text { 管理方法など）にも立ち } \\
\text { 大る必要が出てくる。 }\end{array}$ \\
\hline $\begin{array}{l}\text { 損害発生ま } \\
\text { での時間的 } \\
\text { 間隔 }\end{array}$ & $\begin{array}{l}\text { 通常は, 自動車事 } \\
\text { 故と同時に被害の } \\
\text { 全容を把握できる。 }\end{array}$ & $\begin{array}{l}\text { 遅発損害, 蓄積損 } \\
\text { 害もある。 }\end{array}$ & $\begin{array}{l}\text { 損害の全容が明らかにな } \\
\text { るまでに長期間かかる。 }\end{array}$ \\
\hline $\begin{array}{l}1 \text { 事故の被 } \\
\text { 害者数 }\end{array}$ & 少数 & $\begin{array}{l}\text { 長期にわたり多数 } \\
\text { 発生する可能性が } \\
\text { ある。 }\end{array}$ & $\begin{array}{l}\text { 公平感のある被害者間の } \\
\text { 配分をどの時点でどのよ } \\
\text { うに行えるか。 } \\
\text { (てん補限度額を無制限 } \\
\text { とする引受けはない。) }\end{array}$ \\
\hline
\end{tabular}

10）「自動車損害賠償責任保険の保険金等及び自動車損害賠償責任共済の共済金 等の支払基準」や財団法人日弁連交通事故相談センター発行の「交通事故損害 額算定基準」など。

11）交通事故紛争処理センターや日弁連交通事故相談センターなど。 


\section{3. 被保険者の破産と被害者の救済制度に関する考察}

次に，被保険者が賠償責任保険に加入していたにもかかわらず，被害者が 十分な被害の回復を受けられない典型的な事例を挙げ，その救済制度を設け る場合の考察を行った。

\section{（1）破産債権である損害賠償債権を被保全破産債権として債務者の有する保} 険金請求権を代位行使することはできないとされた事例（保険金請求事件 東京地裁平13（ワ）24005号 平成14年 3 月13日民40部判決 判例時報 1792号，P78)

(1) 事件の概要

$\mathrm{M}$ 水産が製造した「乾燥イカ菓子」を食べた女児（以下「被害者」とい う）が，サルモネラ菌による食中毒に感染し，左大腿骨頭壊死の障害を負 った。

そこで被害者は，その後破産宣告を受けたM水産の破産管財人に対して 損害賠償請求債権確定の訴えを提起し，その額が約 2,090 万円であること が確定したので，M水産と生産物賠償責任保険契約を締結していた損害保 険会社に対し，M水産に代位して2,090万円の保険金を請求した。これに 対して損害保険会社は， あくまで当該損害賠償請求権は破産債権であり， 破産手続きにおいてのみ行使されるべきものであるから，保険金請求権に 対する被害者の代位行使は認められないと主張した。

(2) 争点に対する裁判所の判断の概要

原告の損害賠償請求権は, 破産債権であり破産手続きによってこれを行 使すべきであるから，その手続きを離れて個別に行使することは許されな い。

また，生産物賠償責任保険とは，不測の損害賠償義務を負担することに よる企業の経営上のリスクを回避する目的で締結されるものであるから， 被害者の救済はその反射的利益に止まるといわなければならず，したがっ 
賠償責任保険において保険金から優先的な被害の回復を行う方法について

て，これを一般の損害保険と区別し，被害者による保険金の代位請求を認 めるべきではない。

(3) 事件をめぐってのその後

本件原告は控訴したが，平成14年 7 月 31 日の東京高裁判決も，原審と同 様の理由で控訴を棄却し，平成14年12月20日には，最高裁が上告を育却し たため被害者側の敗訴が確定した ${ }^{12)}$ 。

\section{（2）直接請求権を法的に導入する場合の視点・条件}

(1) 保険者の事実調査や各種立証に関する限界

被害者の直接請求権を法文化することになれば，保険者は保険金支払い にとどまらず，紛争解決当事者となるので，責任の有無や過失割合の判断 などが必須となる。しかし，例えば生産物賠償責任保険の場合，製品の欠 陥があったかどうかは保険者では解らないので，保険者が主体的に紛争を 解決するためには，保険に加入した企業の秘密の部分，例えば製品の製造 工程や日報等の内部資料などに全面的に立ち入ることが必要となってくる。 こうしたことは現実的には困難であり，専門的な調査会社などが一定の権 利を行使して調査することでなければ，因果関係の立証や客観的な責任割 合の判定をすることは出来ないと考えられる。

(2) 保険契約の開示

直接請求権を認女ると被保険者は被害者に保険契約の内容を開示する必 要が生じるが，自賠責保険のように強制保険であればともかく，どのよう な保険契約をしているかは企業秘密であり，開示に法的な強制力を持なせ ない限り制度の実効性が担保されない。したがって，実効性を確保するに は，被害者の加害者（被保険者）に対する保険契約内容の開示請求権や，

12） 2003 年 4 月18日の衆議院財務金融委員会で社民党の阿部智子議員が，この事 件を取り上げ，被害者に対して，破産処理の際に被害者の直接請求権を認める ようなことを考えるとさまざまな法改正が必要となってくると思う旨法務省に 見解を求め，生産物賠償責任保険を管轄しておられる金融庁に対してと考えを 質した。（衆議院 財務金融委員会の会議録議事情報より） 
被保険者の開示義務の規定，保険者の守秘義務の例外（保険契約の存在に ついて被害者から保険者に直接求妓わた場合）の規定の創設が求めら れると思われるが，一般的には開示義務の負担は被保険者にとっては過大 な負担と言わざるを得ないのではないだろうか ${ }^{13)}$ 。

（3) 破産手続き開始，再生手続き開始，更生手続き開始の決定があった場合 加害者の損害賠償責任が確定し，加害者である被保険者が保険金請求権 を有する場合において，加害者について法的倒産処理手続きが開始してい ないときには，被害者は，債権差押命令の申立てを行うことにより，保険

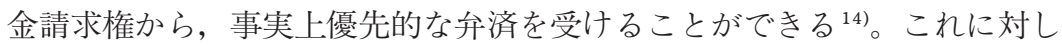
て，保険事故が発生した後に加害者である被保険者が破産手続きの開始の 決定を受けた場合には，保険金が被害者に直接支払われず，被害者は破産 財団からの配当を除いて賠償金の支払いが受けられないという問題が確実 に生じる。法律によってこの問題を解消しない限り，被害者に対する債務 の履行を目的とした賠償保険金が支払われないという事態を解消すること が出来ない。これは，法益を与えるべき重大な場面と言えよう。

(4) 裁判所の関与と保険者の関与

賠償責任の有無，賠償額の妥当性を確保するために，裁判所の関与（裁 判上の判決，和解など）が必要となる。加害者と被害者との間で，法的な 損害賠償責任を離れて不適切な金額で示談がなされる可能性もある。賠償 事故の仮装などによる不正な請求が混在すると，一般的な善意の被保険者， 被害者にも悪影響が及ぶので，裁判所の関与，さらには保険者の関与によ り，損害賠償責任の有無および額の適正性を確保する必要がある。

(5) 人身損害に限ること

保険金が他の債権者に優先して被害者に渡るべきであるということにな

13）破産のケースに限れば，破産債権表に記載するなどにより対策を講じること は可能である。

14）この場合でも，否認権（破産法第72条）との関係の整理や，差押之が競合す る場合の整理は必要である。 
賠償責任保険において保険金から優先的な被害の回復を行う方法について

ると, 自ずとそこには優先するに足りる理由付けが必要になる。確かに被 害者以外の一般債権者は，被保険者と積極的に取引をするといった事象が あるのに対して，被害者は消極的な関わりあいでしかないという特殊性は あるものの，加えてその理由付けをする必要性があると思われる。

その点，人身損害は財物損害に比べて被害者救済の必要性が高いことは 明らかではないかと思われる。また，例えば，強制保険である自賠責保険 の対象が人身損害についての賠償責任に限られていることからも，人身損 害は優先されるべきという理由付けは可能である ${ }^{15)} 。$

6) 保険契約者・被保険者に対抗できる保険者の抗弁事由は被害者に対して も対抗できること

事故発生通知義務や調査協力義務などの被保険者の義務が履行されるこ とは，保険契約上のてん補責任の判断に必要不可欠である。被保険者の保 険金請求権についての優先権である特別先取特権の枠組みにおいてはもち ろん，被害者に固有の権利を認める直接請求権の枠組みにおいても，被害 者の保護は，被保険者が有する保険金請求権の範囲で困られるべきであり， 保険契約者または被保険者に対抗できる全ての抗弁事由を，被害者に対し ても対抗できるものとすべきである。

(7) 被害者のできるだけ公平な救済

被害者多数の場合（生産物賠償責任保険で請求権が競合する場合など） では，自動車保険と異なり保険者が被害者の範囲を特定することが困難で あるが，直接請求がなされた順に支払うのでは保険金額オーバー（限度額 費消）の事案において不公平が生じうるし，全ての被害者が確定するのを 待っているのでは給付が遅れてしまうため, 被害者対応上の問題が生じる ことになる。

15） (7)と関連して，法人の物的損害と個人の人身損害が同時に発生している場合， 法律に熟知した法人が先に差し押さえた結果, 救済すべき個人の人身損害が救 済されないといった事態は避けるべきではないかと思われる。 


\section{（3）特別先取特権を付与する方法について}

加害者が破産した場合などに，保険金が被害者のために使用されることを 実質的に確保することを目的とするのであれば，特別先取特権の方が有効で はないかと考える。特別先取特権は, 政策的な理由から債権者平等の原則を 適用せず，法律によって特定の債権に対して優先弁済権を与えるものである。 特別先取特権には優先弁済機能が認められていることから，債務者について 法的倒産処理手続きが開始しても，法的倒産処理手続き ${ }^{16)}$ にらずに行使す ることができる。

賠償責任保険の保険金請求権を目的とする被害者の特別先取特権が保険法 に定められると，加害者が破産手続き開始決定を受けた場合であっても，被 害者は，破産手続きによらずに加害者が保険者に対して有する保険金請求権 から優先的に弁済を受けることができる。

保険金請求権に対する特別先取特権は，債権差押命令の申立てを被害者が 裁判所に対して行うことによって実行される。裁判所が当該被害者の特別先 取特権の存在を認め, 債権差押命令を保険者に対して送達すると, 被害者は 取立権を行使して保険者から支払いを受けることが可能である。保険者が任 意に支払わない場合には，被害者は保険者を被告として取立訴訟を提起する ことになる。

特別先取特権は，その存在を証明する文書を提出 ${ }^{17)}$ して裁判所に申立てを しなければならない点は被害者にとって手間がかかるものの，犯罪集団によ る不正請求などへの抑止が図られるというメリットがある。

16）破産・再生手続きでは別除権，更生手続きでは更生担保権となる。実際の適 用にあたっては，特別の規定が必要とならないかどうかについて，実務を踏ま えて検討する必要がある。

17）特別先取特権の実行手続きにおいて，被害者はその存在を証明する文書を提 出する必要がある（民事執行法第193条第 1 項）が，不法行為を念頭に置いた 場合には，保険金請求権を証明する書面について，執行力のある公の文書以外 にも，保険者の承認のもとでの示談書面を認めるなど，運用面での工夫が検討 されるべきである。 
賠償責任保険において保険金から優先的な被害の回復を行う方法について

特別先取特権を法定すれば，被害者が多数存在する場合であっても，民事 執行法に従い，ある被害者が特別先取特権の実行として保険金について債権 差押命令を得たときには，他の被害者は一定の期間内に差押え，配当要求な どをして配当を受けることができるので，被害者間の公平性の問題は一定程 度解決できる ${ }^{18)}$ 。被害者救済措置を法定する目的に照らし，特別先取特権は， 適切な方策と考えられる。なお，立法例は国内外に見られる ${ }^{19)}$ 。

なお，特別先取特権で仕組みを構築する場合には，他の先取特権の規律と の整合性の観点から「破産時に限定して認める」という条件や，特別先取特 権を行使する過程で「保険者の関与を条件付ける」という条件を付すことは， 十分な理屈付けが必要になるものと考えられる ${ }^{20)} 。$

\section{4.フランス・ドイッでの事例}

欧州において，「保険金からの優先的な被害の回復の規律」がどのように 決まり，運用されているのかということについて，代表的なフランスとドイ ツについてヒアリングを行った結果を報告する。

\section{(1) フランスの事例}

フランスの保険法では，全ての賠償責任保険に被害者の直接請求権が認め られていると言われている ${ }^{21)}$ 。フランスでの賠償責任保険の引き受けや，事

18）賠償責任保険では，短期間に配当要求することが出来ない可能性もあるので， 期限を遅らせる方策を手当てすることも一考に価する。（民事執行法第165条）

19）原子力損害の賠償に関する法律第 9 条，イタリア民法第2767条など。

20）ただし，これらの条件を法文上記載しなくても，先取特権が行使されるのは 通常破産の場面に限られ，また，「担保権の存在を証する文書」には保険金請 求権が存在することを証明する必要があり，実質的に保険者の関与が不可欠で あることから，問題が生じるおそれは低いとの見方もある。

21）フランス保険法 L.124-3条

被保険者の責任を生ぜしめる加害行為による金銭的影響につき，被害者であ る第三者が，保険者によって支払われるべき金額に達するまで補償されていな い限り，保険者はその金額の全部または一部をその第三者以外の者に支払うこ 
故が発生した場合の対応などの実情と問題点をヒアリングした ${ }^{22)}$ 。

この制度の背景として，保険者からは「加害者が返済不能や行方不明にな ったときのため」という説明があったが，監督庁からは「加害者である保 険契約者を介入させないことで処理が簡略化できる（加害者は罪を認めよ うとしたがらないので，間に入ると解決が難しくなる）ため」との説明が あった。なお，フランスでは自動車や建築，職業に係るものなど義務的賠 償責任保険が100以上ある。

実務的には賠償事故の場合殆どが和解で処理できており，裁判に移行する ケースは少ない。

被害者の直接請求権の対抗要件として, 契約が無効の場合, 約款・契約上 の免責事由に該当する場合，保険金額の限度額を超える場合などは，被害 者に主張できる（日本の自賠法のように被害者の直接請求に対して免責が 主張できないということではない)。

被害者に対して加害者である保険契約者が，保険契約の有無や保険者の名 前など契約内容を開示する仕組みはない。ただし，義務的賠償責任保険 （自動車保険や職業賠責など）では，事故の書類や届出の書類に保険者名 が記載されているので，被害者は保険者を特定することが可能である。任 意賠償責任保険は，保険契約者が保険者に事故を通知して，保険者が解決 のために被害者に接触して初めて保険者名が判明する（保険者名などの情 報提供は法律上明示されていない)。

保険契約者に対しては，保険者が調查権を有している。裁判になると，保 険者は保険契約者との間で約款上「裁判の主導権に関する条項」を結んで おり，これに基づいて保険契約者は保険者の指示に従うことになる。この

とはできない。

これは債務の側から規定しているものであるが，判例で直接請求権が確立し ていると言われている。

22） AGF社，AXA社から実情をヒアリング，ACAM（保険監督庁）で背景な どをヒアリングした。 
賠償責任保険において保険金から優先的な被害の回復を行う方法について

ため，賠償事故の裁判では保険者が前面に出る。

賠償事故の調査は $100 \%$ 外部の専門家に委託する。特に医療分野について は，消費者（被害者）側が使う専門家もいる。消費者（被害者）が専門家 を使った場合，その費用は約款により保険者が払うことになる。両者が専 門家を使っても解決しない場合は，裁判所が刑事面の専門家を任命し，解 決を図ることになる。大企業については，リスク毎に特化した調査会社が 保険契約者である大企業に入って調査し，リスク分析やロスプリベンショ ンを行うだけでなく，事故の際の有無責の判定，原因調査も行う。

\section{(2) ドイツの事例}

ドイツでは08年 1 月施行の改正保険契約法で，これまで自動車賠償保険の みに認められていた被害者の直接請求権が，義務的賠償責任保険全般に拡 大する ${ }^{23)}$ と聞いていたので，検討経緯と問題認識をヒアリングした ${ }^{24)}$

義務的賠償責任保険は，弁護士・会計士などの専門職業人の賠償責任保険 のほかに，犬の飼い主の賠償責任保険など多岐にわたり，対象となる保険 は100種類を超える。義務的責任保険は法定の保険金額が決まっていて， その部分が直接請求権の対象となる。法定限度を超える部分については, 直接請求権の対象とはならない。

○賠償事故が発生した場合，まずは加害者である被保険者とコンタクトをと るのが普通である。被保険者が被害者に賠償金を支払ってから，被保険者 に保険金を支払うことになっている。

被害者の直接請求権に対して，保険者は約款上の免責や契約の失効などが 主張できる。

23）ヒアリング時点における閣議決定案では「義務的賠償責任保険」のみであっ たが，その後成立した改正保険法では，義務的賠償責任保険に加えて，「破産 手続き開始」のケース, 「行方不明」のケースにも被害者の直接請求権が認め られる内容に変更されている。

24) Allianz 社, Munich Re社, Victoria 社, Dr. Langheid（法改正委員）か ら実情や経緯をヒアリングした。 
＜対象が義務的賠償責任保険に限定されたことについて＞

○当初は賠償責任保険全般に直接請求を導入する事が議論されたが，保険者 の実務面における問題点が十分に解消出来ないため，また被害者からの直 接的なクレームが保険者に行くことに危険が大きすぎるという判断から， 結局「義務的賠償責任保険」に落ち着いた。

賠償責任保険全般に導入すると，保険者によるクレームのハンドリングが 難しくなる。保険者が保険契約者に自ら防衛する（リスクを軽減する）と いったことも求为難くなる。また，事故解決に向けての保険契約者の保険 者への協力も十分でなくなる可能性がある。

保険契約者側も直接請求権の法定化には賛成していない。例えば弁護士の 賠償責任保険の場合，弁護士は自分の顧客との良好な関係を維持するため にも，訴訟に対して自分が直接顧客に対応することが必要であると考えて いる。

保険者のディープポケットを見越した請求も多くなる。これにより保険料 も上がることが懸念されていた。

\section{5.まとめ}

以上実務家の立場から，賠償責任保険において保険金から優先的な被害の 回復を行う方法について論じてきたが，根本に戻るとこの問題は「任意」に 加入する賠償責任保険において, 被害者が救済されない場面を洗い出し, 当 該場面で被害者の救済を確実に行うための方策を検討することである。

したがって，保険法で保険金からの優先的な被害の回復に関する規律を設 けるとしても，自ずと場面は限られてくる。場面を限定せずに被害者の救済 を行うというのであれば，全ての加害者が保険に加入していなければ被害者 の全てを救済することは出来ないわけで，そこには高次の政策的判断が加え られ，制度として整っていなければならないものと考えられる。強制保険制 度とすること，および過失責任主義を修正することのない限り，賠償責任保 険の中で画一的に被害者を救済することには限界がある。 
賠償責任保険において保険金から優先的な被害の回復を行う方法について

もちろん，保険者の創意工夫で被害者の救済のために出来るだけのことを 行う努力を妨げるものではない。例えば，保険者がバックアップ体制を拡充 し，示談交渉サービス付きの保険商品を消費者に提供していくことなどは， 大いに歓迎されるべきである。一方で，保険法で強行的に何か制度を設える ならば，実際に全ての保険者にとって実現可能である仕組みにトライするこ とに意義が見出せるのではないか。そうであれば，一歩前進して前掲の「保 険金請求事件 東京地裁平13（ワ）24005号 平成14年 3 月13日民40部判決」 のような，法益を与えるべき重大な場面にフォーカスして，保険者としても 可能な限り努力して, 被害者救済以外の目的に保険金が用いられてしまうこ とを防ぐための制度の実現に向けて，努力をすべきであると考える。

その意味では，既にある制度を活用できる，また救済すべき場面における 懸念事項に適切に対処できるといった観点から「特別先取特権」を設ける方 法が，実務家としてはより望ましいと考えられる。他方「直接請求権」の方 が被害回復の迂遠さを解消できるという感覚があり，また「特別先取特権」 では，担保権の実行ということが個人の被害者から見たときの高いハードル になるのではないかという懸念もある。「直接請求権」で被害の回復を困る

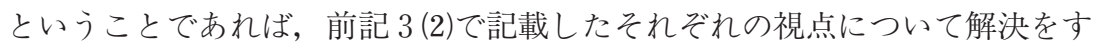
べく適切な条件づけを行うことが必要である。

賠償責任保険に関わる保険契約者，被保険者および被害者それぞれの，賠 償責任保険への期待と, 保険者として実現可能なものとが調和した内容で, 保険法において新なな規律が設けられることを期待する。

(筆者は東京海上日動火災保険株式会社勤務) 